of confusing orders of ascetics with differences of religion. Still, as the passages adduced show, it has its historical value.

It would be interesting to find whether the set of 'thirty tìrthyas' mentioned in line 11 of the Ratnolkā-extract could be similarly confirmed from other Buddhist literature.

C. Bendall.

6. Aśokāstanī Festival.

Hooghly College.

November 26, 1900.

SrR,-The mantra of the Asokāștami festival, quoted by Mr. Anderson at p. 791 of the J.R.A.S. for October, 1900, should run thus:-

Tvām aśoka harābhīṣta madhumāsa-samudbhava

Pivāmi sokasantāpto mām aśokạ̣ sadā kuru.

It means: "O Asoka! you are the favourite of Hara (the Provider), and you are born of Caitra (the Spring). I drink thee. Make thou me, who am oppressed with grief, ever griefless."

Aśokâstami falls on the eighth day of the waxing moon, in the month of Caitra. If the star Punarvasu appears on that day, and if the day happens to be a Wednesday, the merit of bathing in the Brahmaputra is very great. Though you bathe in the Brahmaputra, the eight buds of Jonesia Aśoka must be drunk in Ganges water.

The usual mantra of bathing in the Brahmaputra is the following:-

Brahmaputra mahābhāga Śantanos kulanandana Amoghāgarbhasambhūta pāpam Lauhitya me hara.

"O great Brahmaputra! delight of the race of Ślantanu by his wife Amoghā, O Lauhitya! remove my sins."

Mr. Anderson says he does not remomber who bore Brahmaputra to Brahma. It was Amoghā, the wife of Santanu. I know of nothing in the books about bathing being confined to the north bank. 
Plants are supposed to have their presiding goddesses, and particularly so the nine plants which go by the name of navapatrikā, of which the Aśoka Jonesia is one. Brahmãni, or fire, is the goddess of Kadali; Lakshmī, or prosperity, of Dhānya; and Șokarabitā, or grieflessness, of the Asoka. This may account for the drinking of Assoka buds.-Yours faithfully,

To Professor Rhys Davids,

Khirod Chandra Ray.

Secretary to the Royal Asiatic Society.

\section{The Jänakī-harana.}

Dear Professor Rhys Davids,-It may be of interest to some readers of the Journal to learn that the six verses (Nos. 1751-1755 and 1812) of the Subhāsitāivali which are attributed to a poet Kumāradatta can all be traced, together with the anonymous verse No. 1569, in the Janakiharana of Kumäradāsa (XI : 53, 59, 60, 73, 75. XII: 9. I : 28). Also the verse quoted in Vämana's Kävyãlainkäravrtti, ii, 1,13 , bears all the marks of the same authorship. On these and some other points connected with Kumāradāsa's poem I hope to be allowed to write a little more fully in a subsequent number of the Journal.-Yours very truly,

Dec., 1900.

F. W. Thomas. 